\title{
Strategi Pemberdayaan Wakaf Produktif Dalam Upaya Memakmurkan Umat
}

\author{
Ani Nurbayani ${ }^{1 *}$ \\ 1Jurusan Manajemen Dakwah, Fakultas Dakwah dan Komunikasi, UIN Sunan Gunung Djati, \\ Bandung \\ *Email : Ani.Nurbayani@gmail.com
}

\begin{abstract}
ABSTRAK
Penelitian yang telah dilaksanakan di Wakaf Daarut Tauhid ini berfokus untuk menjawab bagaimana sasaran, tujuan dan hasil yang diperoleh dari pelaksanaan pemberdayaan wakaf secara produktif di Wakaf Daarut Tauhid.Metode yang digunakan dalam penelitian ini adalah metode deskriptif. Karena penelitian ini bertujuan untuk membuat deskripsi, gambaran, atau lukisan secara sistematis dan akurat mengenai usaha-usaha yang dilakukan dalam pemberdayaan wakaf secara produktif dalam upaya memakmurkan umat. Sedangkan untuk teknik pengumpulan data nya, melalui observasi, wawancara dan studi dokumentasi. Kemudian analisis data dilakukan dengan reduksi data kemudian klarifikasi data lalu verifikasi data dan langkah terakhir yaitu menarik kesimpulan.Hasil penilitian menunjukkan bahwa dana wakaf yang telah terhimpun diberdayakan secara produktif dan diperuntukkan untuk penyediaan sarana-sarana, baik sarana ibadah, sarana untuk kegiatan pendidikan, dan sarana ekonomi umat. Meskipun dalam penyediaan sarana-sarana tersebut belum sepenuhnya menjangkau masyarakat secara luas.Dari berbagai data yang diperoleh, maka dapat disimpulkan bahwa strategi-strategi pemberdayaan dana wakaf di wakaf Daarut Tauhid dilaksanakan secara produktif, meskipun kemakmuran umat belum sepenuhnya tercapai.
\end{abstract}

Kata Kunci : Strategi; Pemberdayaan; Wakap Produktif; Memakmurkan Umat.

\section{ABSTRAK}

The research that has been carried out in Daarut Taubid Wakaf focuses on answering how the goals, objectives and results obtained from the productive implementation of waqf empowerment in Daarut Taubid Waqf. The method used in this research is descriptive method. Because this research aims to create a systematic and accurate description, description, or painting of the efforts made in productively empowering waqf in an effort to prosper the people. As for the data collection techniques, through observation, interviews and documentation study. Then the data analysis was carried out by reducing the data, then clarifying the data, then verifying the data and the final 
A.Nurbayani

step, namely drawing conclusions. The results of the research show that the accumulated waqf funds are used productively and are earmarked for the provision of facilities, both religious facilities, educational facilities and the economic means of the people. Even though the provision of these facilities has not fully reached the wider community. From the various data obtained, it can be concluded that the strategies for empowering waqf funds in the Daarut Taubid waqf are carried out productively, even though the prosperity of the people has not been fully achieved. Keywords: Strategy; Empowerment; Productive Wakap; Prosperity of the People.

\section{PENDAHULUAN}

Ditinjau dari aspek ajaran, wakaf merupakan sebuah potensi yang cukup besar untuk bisa dikembangkan sesuai dengan kebutuhan zaman. Apalagi ajaran wakaf ini termasuk bagian dari muamalah yang memiliki jangkauan yang sangat luas. Jika ditinjau dari kekuatan hukum yang dimiliki, ajaran wakaf merupakan ajaran yang bersifat anjuran (sunnah), namun kekuatan yang dimiliki sesungguhnya begitu besar sebagai tonggak menjalankan roda kesejahteraan masyarakat banyak. Lain dengan zakat yang dalam posisi-posisi tertentu akan habis begitu saja karena harus diberikan kepada orang yang berhak. Namun, kalau wakaf justru yang menjadi kelebihannya terletak pada aspek kemanfaatan yang bersifat abadi, sedangkan pokoknya (asalnya) tetap utuh sampai waktu yang lama.

Akan tetapi, saat ini sudah mulai adanya upaya pengelolaan wakaf ke arah yang lebih baik, dikelola dengan cara yang lebih profesional, seperti adanya lembaga-lembaga yang mengelola zakat, infak, shadaqah termasuk pengelolaan wakaf. Lembaga-lembaga tersebut mengelola dana zakat, infak, shadaqah maupun wakaf meliputi penghimpunan sampai kepada pemberdayaan dana zakat, infak, shadaqah dan wakaf tersebut. Bentuk pengelolaan maupun pemberdayaan yang dilakukan setiap lembaga tersebut tentunya dengan strategi yang berbeda-beda, baik dalam cara-cara yang dilakukan untuk mengajak agar orang yang mau berzakat, infak, shadaqah maupun berwakaf bersedia menitipkan zakat, infak, shadaqah maupun wakaf kepada lembaga tersebut. Selain itu, tergantung lembaga tersebut bisa menjaga amanah dengan sebaik-baiknya dan sesuai dengan ketentuan syariah dalam mengelola dana zakat, infak, shadaqah maupun wakafnya.

Wakaf Daarut Tauhid adalah salah satu lembaga yang khusus mengelola wakaf, lembaga ini untuk mengoptimalkan, mengembangkan, dan mengelola wakaf produktif. Wakaf produktif yaitu dana wakaf yang difungsikan sebagai dana penunjang kegiatan pendidikan, dakwah, dan sosial yang berorientasi kepada sebesar-besarnya kemanfaatan ummat secara amanah dan profesional.

Strategi yang dilakukan dalam pemberdayaan wakaf secara produktif di Wakaf Daarut Tauhid ini yaitu dengan memberdayakan dana wakafnya kepada aspek usaha yang menguntungkan, donasi dana wakafnya diperuntukkan kepada kios-kios usaha yang disewakan, usaha property dan perumahan-perumahan, 
gedung serba guna yang disewakan untuk event-event, dan gedung pemberdayaan umat yang digunakan untuk pelatihan-pelatihan baik untuk umum maupun pelatihan untuk pemberdayaan masyarakat secara gratis. Wakaf Daarut Tauhid ini berupaya sebaik mungkin dalam memberdayakan dana wakafnya untuk memakmurkan umat, baik itu dalam kegiatan pendidikan, ekonomi, kesehatan termasuk kepada perkebunan dan pertanian.

Pada dasarnya wakaf itu produktif dalam arti harus menghasilkan karena wakaf dapat memenuhi tujuannya jika telah menghasilkan dimama hasilnya dimanfaatkan sesuai dengan peruntukannya (mauquf alaih). Orang yang pertama melakukan perwakafan adalah Umar bin al Khaththab mewakafkan sebidang kebun yang subur di Khaybar. Kemudian kebun itu dikelola dan hasilnya untuk kepentingan masyarakat. Tentu wakaf ini adalah wakaf produktif dalam arti mendatangkan aspek ekonomi dan kesejahteraan masyarakat.

Setidaknya ada filosofi dasar yang harus ditekankan akan memberdayakan wakaf secara produktif. Pertama, perlu adanya pembaruan pemikiran para nazhir yang sementara ini masih memiliki wawasan konservatif, dan pembentukan badan wakaf yang tidak hanya sekedaar label saja, tapi merupakan kepanjangan dari masyrakat Islam dan amanat undang-undang dan peraturan pemerintah yang sudah ada. Kedua, pola manajemen harus dalam bingkai "proyek yang terintegrasi", bukan bagian-bagian dari biaya yang terpisah-pisah. Dengan bingkai proyek sesungguhnya, dana wakaf akan dialokasikan untuk program pemberdayaan dengan segala macam biaya yang terangkum didalamnya. Ketiga, adanya asas transparansi dan accountability di mana badan wakaf dan lembaga yang dibantunya harus melaporkan setiap tahun akan prose pengelolaan dana kepada umat Islam dalam bentuk audited financial report termasuk kewajaran dari masing-masing pos biayanya.

Metode penilitian yang digunakan adalah metode deskriptif, yaitu suatu metode dalam meneliti status sekelompok manusia, suatu objek, suatu set kondisi, suatu sistem pemikiran, ataupun suatu kelas peristiwa pada masa sekarang. Tujuan dari penelitian deskriptif ini adalah untuk membuat deskripsi, gambaran atau lukisan secara sistematis, faktual, dan akurat mengenai fakta-fakta, sifat-sifat serta hubungan antarfenomena yang diselidiki (Moh. Nazir, 2014:43). Hal ini dimaksudkan untuk menggambarkan, menjelaskan bagaimana strategi pemberdayaan wakaf secara produktif yang dilakukan oleh Wakaf Daarut Tauhid. Dengan metode ini dan melalui observasi, wawancara, dan studi kepustakaan yang menyeluruh dalam objek penelitian ini diharapkan dapat menunjang tujuan yang diharapkan. Data yang telah didapat kemudian dianalisis dalam rangka mendapatkan data secara benar, akurat dan lengkap berdasarkan hasil pengumpulan data dan pengolahan data secara sistematis. 


\section{LANDASAN TEORITIS}

Secara teknis syariah, wakaf sering kali diartikan sebagai aset (harta) yang dialokasikan untuk kemanfaatan umat dimana substansi atau pokoknya ditahan, sementara manfaatnya boleh dinikmati untuk kepentingan umum. Secara administratif wakaf dikelola oleh nazhir yang merupakan pengemban amanah waqif (yang memberi wakaf). Nazhir harus bisa mengelola wakaf yang diterima dari waqif sesuai dengan ketentuan syariah.

Persoalan wakaf tidak terlepas dari berbagai problematika yang berkembang, khususnya di Indonesia. Sejak dan setelah datangnya Islam, sebagian besar masyarakat Indonesia melaksanakan wakaf berdasarkan paham keagamaan yang dianut, yaitu paham Syafi'iyah dan adat kebiasaan setempat. Sebelum adanya UU No. 5 Tahun 1960 tentang: Peraturan Dasar Pokok Agraria dan Peraturan Pemerintah No. 28 Tahun 1977 tentang: Perwakafan Tanah Milik, masyarakat Islam Indonesia masih menggunakan kebiasaan-kebiasaan keagamaan, seperti kebiasaan melakukan perbuatan hukum perwakafan tanah secara lisan atas dasar saling percaya kepada seseorang atau lembaga tertentu, kebiasaan memandang wakaf sebagai amal shaleh yang mempunyai nilai mulia di hadirat Tuhan tanpa harus melalui prosedur administratif, dan harta wakaf dianggap milik Allah semata yang siapa saja tidak akan berani mengganggu gugat tanpa seizin Allah.

Praktik pelaksanaan wakaf semacam ini, pada paruh perjalananya harus diakui memunculkan persoalan mengenai validitas legal tentang harta wakaf yang berujung pada timbulnya persengketaan-persengketaan karena tiadanya buktibukti yang mampu menunjukkan bahwa benda-benda bersangkutan telah diwakafkan. Selain itu, harta yang boleh diwakafkan (mauquf bih), yang dalam peraturan perundangan sebelum UU No. 41 Tahun 2004 tentang wakaf seperti (PP No: 28 Tahun 1977) hanya menyangkut perwakafan benda tak bergerak yang lebih banyak dipergunakan untuk kepentingan yang tidak produktif, seperti masjid, madrasah, kuburan, yayasan yatim piatu, pesantren, sekolah dan sebagainya. Sehingga wakaf kurang bisa dikembangkan secara optimal.

Kemudian, selama ini yang menjadi hambatan riil dalam pengembangan wakaf di Indonesia adalah keberadaan nazhir (pengelola) wakaf yang masih tradisional. Hal itu dikarenakan masih kuatnya paham mayoritas umat Islam yang masih stagnan (beku) terhadap persoalan wakaf. Rendahnya kualitas Sumber Daya Manusia (SDM) nazhir wakaf. Kemudian lemahnya kemauan para nazhir wakaf juga menambah ruwetnya kondisi wakaf di tanah air. Padahal, kehadiran nazhir sebagai pihak yang diberikan kepercayaan dalam pengelolaan harta wakaf sangatlah penting.

Pada awalnya konsep strategi (strategy) didefinisikan sebagai berbagai cara untuk mencapai tujuan (ways to achieve ends). Konsep generik ini terutama sesuai dengan perkembangan awal penggunaan konsep strategi yang digunakan dalam 
dunia militer. Strategi dalam dunia militer adalah berbagai cara yang digunakan oleh panglima perang untuk mengalahkan musuh dalam suatu peperangan (war). Sedangkan cara yang digunakan oleh pasukan untuk memenangkan pertempuran (battle) digunakan istilah taktik.

Menurut Udaya, strategi dapat didefinisikan sebagai penentuan dari tujuan dasar jangka panjang dan sasaran sebuah perusahaan dan penerimaan dari serangkaian tindakan serta alokasi dari sumber-sumber yang dibutuhkan untuk melaksanakan tujuan tersebut (Udaya, 1994:134). Selain itu, strategi adalah rencana yang menyeluruh dalam rangka pencapaian tujuan organisasi (Erni \& Kurniawan, 2010:147).

Gerry Johnson dan Kevan Scholes, dalam buku mereka berjudul Exploring Corporate Strategy, menawarkan definisi strategi: 'Strategi adalah arah dan jangkauan suatu organisasi dalam jangka panjang: yang mencapai keunggulan organisasi melalui konfigurasi sumber dayanya dalam suatu lingkungan yang menantang, untuk memenuhi berbagai kebutuhan pasar dan harapan pihak-pihak yang berkepentingan. Sementara itu, Michael Porter memberikan definisi yang lebih jelas dan berasal dari suatu sudut pandang yang berbeda: 'Strategi seharusnya berkaitan dengan apa yang akan membuat unik'. Ansoff, yang diakui sebagai bapak manajemen strategi, mengatakan bahwa strategi merupakan 'suatu aturan untuk membuat keputusan-keputusan', dan beberapa pihak memperdebatkannya. Ia membedakan antara sasaran (objective), yang menentukan tujuan dengan strategi yang menetapkan jalur bagi tujuan. Ia percaya sepenuhnya bahwa 'struktur mengikuti strategi’. Keputusan-keputusan strategi harus menjawab tiga pertanyaan mendasar:

Apakah sasaran dan tujuan perusahaan?

Perlukah perusahaan berdiversifikasi, dan bila demikian dalam apa saja dan seberapa kuat?

Bagaimana perusahaan seharusnya berkembang dan mengeksploitasi posisi pasar produknya saat ini ? (Edward Russell-Walling, 2008:48)

Pemberdayaan (empowerment) didefinisikan Conger dan Kanungo sebagai sebuah proses meningkatkan perasaan mampu pada anggota organisasi dengan mengidentifikasi kondisi-kondisi yang menyebabkan ketidakberdayaan dan menyingkirkan kondisi-kondisi tersebut melalui praktik organisasional formal dan teknik informal menyediakan informasi yang berharga.

Konsep pemberdayaan (empowerment) sebagai upaya memberikan otonomi, wewenang, dan kepercayaan kepada setiap individu dalam suatu organisasi, serta mendorong mereka untuk kreatif agar dapat menyelesaikan tugasnya sebaik mungkin. Di sisi lain Paul (1987) dalam Prijono dan Pranarka (1996) mengatakan bahwa pemberdayaan berarti pembagian kekuasaan yang adil sehingga meningkatkan kesadaran politis dan kekuasaan pada kelompok yang

Tadbir: Jurnal Manajemen Dakwah Vol. 5 No. 2 (2020) 167-188 
lemah serta memperbesar pengaruh mereka terhadap proses dan hasil-hasil pembangunan. Sedangkan konsep pemberdayaan menurut Friedman (1992) dalam hal ini pembangunan alternatif menekankan keutamaan politik melalui otonomi pengambilan keputusan untuk melindungi kepentingan rakyat yang berlandaskan pada sumberdaya pribadi, langsung melalui partisipasi, demokrasi dan pembelajaran sosial melalui pengamatan langsung.

Jika dilihat dari proses operasionalisasinya, maka ide pemberdayaan memiliki dua kecenderungan, antara lain : pertama, kecenderungan primer, yaitu kecenderungan proses yang memberikan atau mengalihkan sebagian kekuasaan, kekuatan, atau kemampuan (power) kepada masyarakat atau individu menjadi lebih berdaya. Proses ini dapat dilengkapi pula dengan upaya membangun asset material guna mendukung pembangunan kemandirian mereka melalui organisasi; dan kedua, kecenderungan sekunder, yaitu kecenderungan yang menekankan pada proses memberikan stimulasi, mendorong atau memotivasi individu agar mempunyai kemampuan atau keberdayaan untuk menentukan apa yang menjadi pilihan hidupnya melalui proses dialog. Dua kecenderungan tersebut memberikan (pada titik ekstrem) seolah berseberangan, namun seringkali untuk mewujudkan kecenderungan primer harus melalui kecenderungan sekunder terlebih dahulu (Sumodiningrat, Gunawan, 2002).

Wakaf produktif adalah sebuah skema pengelolaan donasi wakaf dari umat, yaitu dengan memproduktifkan donasi tersebut, hingga mampu menghasilkan surplus yang berkelanjutan. Donasi wakaf dapat berupa benda bergerak, seperti uang dan logam mulia, maupun benda tidak bergerak, seperti tanah dan bangunan. Surplus wakaf produktif inilah yang menjadi sumber dana abadi bagi pembiayaan kebutuhan umat, seperti pembiayaan pendidikan dan pelayanan kesehatan yang berkualitas.

Peruntukan wakaf di Indonesia kurang mengarah pada pemberdayaan ekonomi umat dan cenderung hanya untuk kepentingan kegiatan-kegiatan ibadah khusus lebih karena dipengaruhi oleh keterbatasan umat Islam akan pemahaman wakaf, baik mengenai harta yang diwakafkan, peruntukkan wakaf maupun nazir (pengelola) wakaf. Mengingat salah satu tujuan wakaf ialah menjadikannya sebagai sumber dana yang produktif, tentu memerlukan nazhir yang mampu melaksanakan tugas-tugasnya secara profesional dan bertanggung jawab. Apabila nazhir tidak mampu melaksanakan tugas (kewajiban) nya, maka pemerintah wajib menggantinya dengan tetap menjelaskan alasan-alasannya (Achmad Djunaidi \& Thobieb Al-Asyhar, 2005:47-54).

Perwakafan di Indonesia pada awalnya diatur dalam PP No. 28 Tahun 1977 tentang perwakafan tanah milik dan sedikit tercover dalam UU No. 5 Tahun 1960 tentang Peraturan Dasar Pokok Agraria. Namun, peraturan perundangan tersebut hanya mengatur benda-benda wakaf tidak bergerak dan peruntukkannya lebih banyak untuk kepentingan ibadah mahdhah, seperti masjid, musholla, pesantren, 
kuburan dan lain-lain. Karena keterbatasan cakupannya, peraturan perundangan perwakafan diregulasi agar perwakafan dapat diberdayakan dan dikembangkan secara lebih produktif. Regulasi peraturan perundangan perwakafan tersebut berupa UU No. 41 Tahun 2004 tentang Wakaf dan Peraturan Pemerintah No. 42 Tahun 2006 tentang Pelaksanaannya. Kedua peraturan perundangan tersebut memiliki urgensi, yaitu selain untuk kepentingan ibadah mahdhah, juga menekankan perlunya pemberdayaan wakaf secara produktif untuk kepentingan sosial (kesejahteraan umat).

Menurut Undang-Undang No. 41 Tahun 2004 tentang wakaf (2007:3), wakaf adalah perbuatan hukum wakif (pihak yang mewakafkan) untuk memisahkan dan/atau menyerahkan sebagian harta benda miliknya untuk dimanfaatkan selamanya atau untuk jangka waktu tertentu sesuai dengan kepentingannya guna keperluan ibadah dan/atau kesejahteraan umum menurut syariah.

Pada awalnya konsep strategi (strategy) didefinisikan sebagai berbagai cara untuk mencapai tujuan (ways to achieve ends). Konsep generik ini terutama sesuai dengan perkembangan awal penggunaan konsep strategi yang digunakan dalam dunia militer. Strategi dalam dunia militer adalah berbagai cara yang digunakan oleh panglima perang untuk mengalahkan musuh dalam suatu peperangan (war). Sedangkan cara yang digunakan oleh pasukan untuk memenangkan pertempuran (battle) digunakan istilah taktik.

Menurut Udaya, strategi dapat didefinisikan sebagai penentuan dari tujuan dasar jangka panjang dan sasaran sebuah perusahaan dan penerimaan dari serangkaian tindakan serta alokasi dari sumber-sumber yang dibutuhkan untuk melaksanakan tujuan tersebut (Udaya, 1994:134). Selain itu, strategi adalah rencana yang menyeluruh dalam rangka pencapaian tujuan organisasi (Erni \& Kurniawan, 2010:147).

Gerry Johnson dan Kevan Scholes, dalam buku mereka berjudul Exploring Corporate Strategy, menawarkan definisi strategi: 'Strategi adalah arah dan jangkauan suatu organisasi dalam jangka panjang: yang mencapai keunggulan organisasi melalui konfigurasi sumber dayanya dalam suatu lingkungan yang menantang, untuk memenuhi berbagai kebutuhan pasar dan harapan pihak-pihak yang berkepentingan. Sementara itu, Michael Porter memberikan definisi yang lebih jelas dan berasal dari suatu sudut pandang yang berbeda: 'Strategi seharusnya berkaitan dengan apa yang akan membuat unik'. Ansoff, yang diakui sebagai bapak manajemen strategi, mengatakan bahwa strategi merupakan 'suatu aturan untuk membuat keputusan-keputusan', dan beberapa pihak memperdebatkannya. Ia membedakan antara sasaran (objective), yang menentukan tujuan dengan strategi yang menetapkan jalur bagi tujuan. Ia percaya sepenuhnya bahwa 'struktur mengikuti strategi'.

Tadbir: Jurnal Manajemen Dakwah Vol. 5 No. 2 (2020) 167-188 
Pemberdayaan (empowerment) didefinisikan Conger dan Kanungo sebagai sebuah proses meningkatkan perasaan mampu pada anggota organisasi dengan mengidentifikasi kondisi-kondisi yang menyebabkan ketidakberdayaan dan menyingkirkan kondisi-kondisi tersebut melalui praktik organisasional formal dan teknik informal menyediakan informasi yang berharga.

Konsep pemberdayaan (empowerment) sebagai upaya memberikan otonomi, wewenang, dan kepercayaan kepada setiap individu dalam suatu organisasi, serta mendorong mereka untuk kreatif agar dapat menyelesaikan tugasnya sebaik mungkin. Di sisi lain Paul (1987) dalam Prijono dan Pranarka (1996) mengatakan bahwa pemberdayaan berarti pembagian kekuasaan yang adil sehingga meningkatkan kesadaran politis dan kekuasaan pada kelompok yang lemah serta memperbesar pengaruh mereka terhadap proses dan hasil-hasil pembangunan. Sedangkan konsep pemberdayaan menurut Friedman (1992) dalam hal ini pembangunan alternatif menekankan keutamaan politik melalui otonomi pengambilan keputusan untuk melindungi kepentingan rakyat yang berlandaskan pada sumberdaya pribadi, langsung melalui partisipasi, demokrasi dan pembelajaran sosial melalui pengamatan langsung.

Jika dilihat dari proses operasionalisasinya, maka ide pemberdayaan memiliki dua kecenderungan, antara lain : pertama, kecenderungan primer, yaitu kecenderungan proses yang memberikan atau mengalihkan sebagian kekuasaan, kekuatan, atau kemampuan (power) kepada masyarakat atau individu menjadi lebih berdaya. Proses ini dapat dilengkapi pula dengan upaya membangun asset material guna mendukung pembangunan kemandirian mereka melalui organisasi; dan kedua, kecenderungan sekunder, yaitu kecenderungan yang menekankan pada proses memberikan stimulasi, mendorong atau memotivasi individu agar mempunyai kemampuan atau keberdayaan untuk menentukan apa yang menjadi pilihan hidupnya melalui proses dialog. Dua kecenderungan tersebut memberikan (pada titik ekstrem) seolah berseberangan, namun seringkali untuk mewujudkan kecenderungan primer harus melalui kecenderungan sekunder terlebih dahulu (Sumodiningrat, Gunawan, 2002).

Wakaf produktif adalah sebuah skema pengelolaan donasi wakaf dari umat, yaitu dengan memproduktifkan donasi tersebut, hingga mampu menghasilkan surplus yang berkelanjutan. Donasi wakaf dapat berupa benda bergerak, seperti uang dan logam mulia, maupun benda tidak bergerak, seperti tanah dan bangunan. Surplus wakaf produktif inilah yang menjadi sumber dana abadi bagi pembiayaan kebutuhan umat, seperti pembiayaan pendidikan dan pelayanan kesehatan yang berkualitas.

\section{HASIL DAN PEMBAHASAN}

Berdasarkan penelitian yang telah dilakukan di Wakaf Daarut Tauhid, berikut ini pembahasan dari pertanyaan-pertanyaan yang telah dikemukakan mengenai 
bagaimana sasaran, tujuan dan hasil yang diperoleh dari strategi pemberdayaan wakaf secara produktif dalam upaya memakmurkan umat.

\section{Sasaran Strategi Pemberdayaan Wakaf Produktif}

Wakaf harus dimanfaatkan dalam batas-batas yang sesuai dan diperbolehkan Syariat Islam. Karena pada dasarnya, wakaf merupakan amal yang mendekatkan diri manusia kepada Allah SWT. karena itu, mauquf'alaih (yang diberi wakaf) haruslah pihak kebajikan. Dalam hal ini, peran nąhir (pengelola wakaf) harus benar-benar profesional dalam memberdayakan dana wakaf.

Terdapat perbedaan pendapat antara para faqih mengenai jenis ibadah wakaf ini, apakah ibadah wakaf menurut pandangan Islam ataukah menurut keyakinan wakif atau keduanya, yaitu menurut pandangan Islam dan keyakinan wakif

a. Madzhab Hanafi mensyaratkan agar mauquf'alaib ditujukan untuk ibadah menurut pandangan Islam dan menurut keyakinan wakif. Jika tidak terwujud salah satunya, maka wakaf tidak sah. Karena itu :

1) Sah wakaf orang Islam kepada semua syi'ar-syi'ar Islam dan pihak kebajikan, seperti orang-orang miskin, rumah sakit, tempat penampungan dan sekolah. Adapun wakaf selain syi'ar-syi'ar Islam dan pihak-pihak kebajikan hukumnya tidak sah, seperti klub judi dan lain-lain.

2) Sah wakaf nonmuslim kepada pihak kebajikan umum seperti tempat ibadah dalam pandangan islam seperti pembangunan mesjid, biaya mesjid, bantuan kepada jamaah haji dan lain-lain. Adapun kepada selain pihak kebajikan umum dan tempat ibadah dalam pandangan agamanya saja seperti pembangunan gereja, biaya pengurusan gereja hukumnya tidak sah.

b. Madzhab Maliki mensyaratkan agar mauquf 'alaih untuk ibadah wakaf ini menurut pandangan wakif. Sah wakaf muslim kepada semua syi'ar Islam dan badan-badan sosial umum. Tidak sah wakaf non muslim kepada syiarsyiar Islam.

c. Madzhab Syafi'i dan Hambali mensyaratkan agar mauquf 'alaih adalah ibadah menurut pandangan Islam saja, tanpa memandang keyakinan wakif. Karena itu sah wakaf muslim dan non muslim kepada badan-badan sosial seperti penampungan, tempat peristirahatan, badan kebajikan dalam Islam seperti masjid. Tidak sah wakaf muslim dan non muslim kepada badan-badan sosial yang tidak sejalan dengan Islam seperti gereja.

Secara garis umum, pihak yang menerima wakaf adalah kebajikan umum dan tidak ditentukan secara lebih jelas oleh nash. Namun para ulama berbeda pendapat, apakah peruntukan wakaf hanya untuk orang 
Islam sendiri atau boleh juga pihak-pihak yang beragama non muslim ? Untuk menentukkannya diperlukan sebuah kajian yang terkait dengan kondisi sosial yang ada atau melalui permintaan persetujuan dari para wakif.

Berdasarkan yang tertulis dalam Undang-undang RI No. 41 Tahun 2004, bagian kedelapan tentang peruntukan harta benda wakaf pasal 22 bahwa harta benda wakaf hanya diperuntukkan bagi :

a. Sarana dan kegiatan ibadah

b. Sarana dan kegiatan pendidikan serta kesehatan

c. Bantuan kepada fakir miskin, anak terlantar, yatim piatu, bea siswa

d. Kemajuan dan peningkatan ekonomi umat

e. Kemajuan kesejahteraan umum lainnya yang tidak bertentangan dengan syariah dan peraturan perundang-undangan

Wakaf Daarut Tauhid memperuntukkan dana wakaf yang sudah terhimpun, dengan dibangunnya beberapa sarana untuk kemanfaatan umat, diantaranya :

a. Pembangunan Mesjid Daarut Tauhid sebagai sarana untuk kegiatan ibadah

Pembangunan dan perluasan mesjid Daarut Tauhid dianggap penting dan sangat dibutuhkan, karena faktor penyebabnya yaitu meningkatnya jumlah jamaah dan peran strategis masjid yang tidak sekedar tempat beribadah. Masjid Daarut Tauhid dikenal sebagai salah satu masjid dengan aktivitas yang jamaah yang padat. Selain dilaksanakannya shalat lima waktu yang secara berjamaah yang harus antri bergiliran, aktivitas keagamaan juga selalu berjalan "hidup" di masjid Daarut Tauhid ini.

Sejak dua tahun ini, kapasitas Masjid Daarut Tauhid sudah tidak mampu menampung jamaah yang beribadah. Ketidaknyamanan menjadi keluhan yang sering disampaikan. Padahal, masjid sebagai representasi dari rumah Allah seyogyanya menjadi tempat yang nyaman untuk beribadah. Dengan adanya tambahan lahan wakaf seluas $380 \mathrm{~m}^{2}$, sehingga total luas masjid Daarut Tauhid menjadi $2.866 \mathrm{~m}^{2}$, permasalahan tersebut semoga dapat diatasi.

Masjid Daarut Tauhid diharapkan berperan strategis menjadi model pengelolaan masjid yang profesional di Indonesia. Yakni bagaimana masjid difungsikan sebagaimana layaknya zaman Rasulullah. Masa ketika masjid berfungsi bukan sekedar tempat beribadah saja, namun juga sebagai madrasah atau pusat pendidikan umat. Melalui perluasan masjid, akan dibangun ruangruang kelas, perpustakaan, roof garden. Semua fasilitas itu dapat mendukung Masjid Daarut Tauhid sebagai sebuah tempat layaknya institut. 
Masjid Daarut Tauhid akan menjadi miniatur masjid di Indonesia yang dikelola secara baik, benar, dan mandiri. Menjadi role model pengelolaan masjid yang mengedepankan aspek manajemen profesional dan dapat menghilangkan kesan pengelolaan masjid yang tidak mandiri atau tergantung uluran tangan dari pihak lain.

Dana wakaf yang telah terhimpun untuk masjid ini akan digunakan pembangunan masjid Daarut Tauhid ke arah barat. Konsep masjid ini lebih berkesan hijau dengan tanaman di sekitar masjid, lebih berkesan masjid dengan didukung ornamen eksterior. Donasi wakaf tunai juga digunakan untuk menyediakan sarana dan prasarana ibadah masjid, diantaranya: karpet, pompa air, sound system, perlengkapan kebersihan, hijab, renovasi bangunan, renovasi toilet atau tempat wudhu dan penambahan sarana air bersih masjid.

Untuk berwakaf di Wakaf Daarut Tauhid, khususnya untuk pembangunan masjid, bisa dengan beberapa cara :

1) Wakaf uang tunai, berwakaf pembangunan perluasan dan fasilitas Masjid Daarut Tauhid diantaranya berupa uang tunai sebesar 5 juta $/ \mathrm{m}^{2}$.

2) Wakaf bahan bangunan, berwakaf berupa bahan bangunan yang pada umumnya digunakan dalam proses mendirikan sebuah bangunan yaitu dengan menyediakan material bahan bangunan. Bahan-bahan bangunannya berupa : semen, pasir , besi, bata dan bahan bangunan lainnya.

3) Wakaf tenaga dan keahlian, berkontribusi dengan menyedekahkan atau mewakafkan tenaga dan atau keahlian di bidang tertentu dalam proses pembangunan mesjid ini, diantaranya : membantu saat proses pengecoran, bisa bersedekah dengan menyediakan konsumsi untuk para pekerja, yang mempunyai perkebunan bisa bersedekah dengan hasil kebunnya, yang mempunyai keahlian di bidang tertentu bisa untuk menyedekahkan keahlian atau ilmunya.

4) Wakaf fasilitas masjid, berwakaf fasilitas atau sarana penunjang masjid secara paket. Masjid Daarut Tauhid dibangun dengan lima lantai lengkap dengan fasilitas dari tiap lantainya.

\section{Sarana untuk kegiatan pendidikan}

Wakaf Daarut Tauhid menyediakan sarana untuk kegiatan pendidikan. Program wakaf ini adalah program wakaf untuk pembangunan sekolah berupa ruang kelas mulai dari SMP, SMA, SMK Boarding Schools dan Ma'had Tafaquh Fiddin dan sarana asrama. 
Donasi wakaf akan dimanfaatkan untuk memanfaatkan untuk mendukung aktifitas belajar siswa/siswi yang cerdas, kompetitif, berkarakter baik (ikhlas, jujur, tawadhu) dan kuat (berani, disiplin, tangguh) serta memiliki akhlak yang mulia.

1) Pengadaan Ruang Kelas dibangun untuk kebutuhan SMP, SMA masing-masing tiga lantai yang terletak di eco pesantren dan empat lantai di Gegerkalong.

2) Pengadaan Asrama dibangun untuk kebutuhan SMP, SMA dan Ma'had di eco pesantren dan Gegerkalong Girang sebanyak tiga lantai.

Adapun investasi wakaf sekolah ruang kelas dan asrama ini adalah :

1) Wakaf pembangunan sekolah dan asrama : Rp 4.500.000/ $\mathrm{m}^{2}$

2) Wakaf pembangunan sekolah dan asrama: $\mathrm{Rp} 2.250 .000 / 0,5 \mathrm{~m}^{2}$

3) Wakaf pembangunan sekolah dan asrama : Rp 45.000/1 $\mathrm{cm}^{2}$

Donasi wakaf yang diperuntukkan untuk sarana pendidikan ini merupakan program wakaf untuk menunjang kegiatan pendidikan yang dilaksanakan oleh Yayasan Daarut Tauhid, karena semakin banyaknya siswasiswa yang sekolah di sekolah di bawah Yayasan Daarut Tauhid dan para santri yang mengikuti pendidikan di pondok pesantren seperti santri DQ (Daarul Quran), APW, PMK, PPM, SSG (Santri Siap Guna) dan santri-santri pada umumnya, selain itu diadakannya program wakaf ini untuk menambah sarana dan prasarana yang masih kurang untuk kegiatan pendidikan yang dilakukan oleh siswa/siswi, sehingga kegiatan pendidikan yang dilaksanakan berjalan dengan baik dan memberikan kenyamanan kepada siswa/siswi dan para santri dalam kegiatan belajarnya.

b. Wakaf Produktif

Wakaf produktif adalah mengubah aset wakaf menjadi aspek usaha yang menguntungkan. Pendapatan dari usaha inilah yang kemudian dapat digunakan untuk kegiatan pendidikan, dakwah dan sosial. Wakaf produktif bermakna suatu upaya transformasi pengelolaan wakaf (harta benda atau pokok tetap) secara profesional untuk meningkatkan atau menambah nilai manfaat wakaf tersebut sesuai dengan peruntukannya (manqufalaib).

Dana wakaf yang terhimpun untuk didonasikan kepada wakaf produktif ini diperuntukan, diantaranya :

1) Area foodcourt dan kios-kios usaha yang disewakan, kios-kios yang sudah dibangun berjumlah sekitar sepuluh kios dengan berbagai produk yang dijual, seperti pakaian, kerudung, buku-buku, kios obat herbal, kios alat kecantikan, kios aksesoris kerudung, dan lain-lain. 
2) Usaha property atau perumahan-perumahan, yang terletak di Perumahan Gegerkalong Girang Baru.

3) Ruang publik ATM, ATM yang tersedia yaitu ATM bank BRI, bank Mandiri, bank BNI dan ATM Bersama.

4) Gedung serba guna, yang disewakan untuk event-event, pameran, pernikahan dan lain-lain, ada Gedung Darul Hajj dan Daarul Jannah Cottage.

5) Gedung pemberdayaan ummat, yang digunakan untuk pelatihanpelatihan baik untuk umum maupun pelatihan untuk pemberdayaan masyarakat secara gratis. Gedung ini akan dibangun di beberapa wilayah provinsi sebagai bagian dari kantor cabang DPU Daarut Tauhid.

\section{Tujuan Strategi Pemberdayaan Wakaf Produktif}

Wakaf bertujuan untuk memberikan manfaat atau faedah harta yang diwakafkan kepada orang yang berhak dan dipergunakan sesuai dengan ajaran syariah Islam. Hal ini sesuai dengan fungsi wakaf yang disebutkan pasal 5 UU no. 41 tahun 2004 yang menyatakan bahwa wakaf berfungsi untuk mewujudkan potensi dan manfaat ekonomis harta benda wakaf untuk kepentingan ibadah dan untuk memajukan kesejahteraan umum.

Wakaf bisa disalurkan kepada berbagai macam bentuk. Akan tetapi akan lebih indah jika bisa berwakaf kepada sesuatu hal yang bisa memfasilitasi para ulama, dan lahirnya para pemimpin umat. Karena kehadiran para ulama bisa menjadi pembimbing umat untuk mendapatkan hidayah dan taufik Allah SWT. kehadiran para pemimpin bisa menjadi pengayom umat, menegakkan hukum, dan mengajak masyarakat untuk bisa lebih dekat kepada Allah SWT.

Jika wakaf bisa disalurkan kepada fasilitas-fasilitas yang kemudian melahirkan sosok-sosok tersebut, maka ini adalah wakaf yang sangat strategis. Wakaf yang disalurkan untuk membangun fasilitas pencetak kader ulama dan para pemimpin yang adil dan bijaksana. Wakaf yang demikian akan memberikan multi efek yang memberdayakan.

a. Pembangunan Sarana Ibadah

Tujuan dari adanya strategi pemberdayaan wakaf dengan dibangunnya sarana ibadah dari dana wakaf, diantaranya yaitu sebagai berikut :

1) Memfasilitasi orang-orang yang akan shalat ketika berkunjung ke Yayasan Daarut Tauhid untuk berbagai keperluan apapun. 
2) Setiap yayasan yang banyak melaksanakan kegiatan keagamaan, tentunya harus ada masjid sebagai tempat pelaksanaan berbagai kegiatan keagamaan tersebut, begitu pula di Yayasan Daarut Tauhid.

3) Dengan perluasan masjid dan penyediaan berbagai sarana penunjang masjid dari dana wakaf, bertujuan untuk menampung lebih banyak jamaah karena sebelumnya banyak jamaah yang harus antri bergiliran untuk melaksanakan shalat.

4) Mengembangkan fungsi mesjid yang tidak hanya sebagai sarana ibadah saja, akan tetapi menjadi sarana untuk kegiatan keagamaan yang lainnya.

Masjid adalah rumah Allah SWT. beruntunglah bagi siapa saja yang diberikan kesempatan oleh Allah untuk memakmurkan rumah-Nya. Beruntunglah orang-orang yang diberikan jalan kebaikan oleh Allah SWT. dengan cara didekatkan tempat tinggalnya dengan masjid, didataangkan kepadanya para petugas pengumpul dana wakaf untuk memakmurkan masjid. Beruntunglah orang-orang ini yang kemudian mengambil dengan segera kesempatan tersebut sebaik mungkin.

Rasulullah SAW. Setibanya di Madinah setelah peristiwa hijrah yang beliau lakukan adalah membangun masjid. Bukan semata-mata hanya tempat shalat saja. Melainkan disinilah Rasulullah membina pusat kekuatan dan kesatuan umat, mendidik dan membangun sumber daya manusia umat Islam generasi pertama. Di masjid pertama ini Rasulullah SAW. Membangun aspek rohani, jasmani dan intelektual sahabat-sahabatnya.

Masjid adalah sebaik-baiknya tempat di muka bumi. Tempat dimana didalamnya tiada hal yang patut dikerjakan selain dari ibadah kepada Allah SWT. dan mengagungkan-Nya.Allah SWT. berfirman, "Dan sesunggubnya masjid-masjid itu adalah kepunyaan Allah. Maka janganlah kamu menyembah seseorangpun didalamnya disamping (menyembah) Allah.” (QS. Al Jin:18)

Masjid juga adalah tempat yang paling Allah SWT. cintai di muka bumi. Sehingga, barangsiapa yang ingin dicintai Allah, maka cintailah tempat yang dia cintai. Barangsiapa yang sungguh-sungguh mencintai Allah, maka ia akan mencintai tempat yang Allah cintai, yaitu masjid.

Masjid pun adalah bagian dari syiar dan panji-panji Islam. Di dalam keterangan yang diriwayatkan Muttafaq'alaih disebutkan bahwa dahulu jika Rasulullah SAW. sedang dalam misi jihad, kemudian beliau sudah mendekati negeri kafir yang memusuhi Islam, maka sebelum beliau menyerukan perintah penyerangan, beliau terlebih dahulu meminta para sahabat untuk memeriksa apakah di dalam negeri tersebut ada masjid atau ada kumandang adzan. Jika ada, maka Rasulullah SAW. akan membatalkan serangan tersebut.

Kehadiran masjid akan memberikan kemudahan dan kelekuasaan bagi 
orang-orang untuk shalat di awal waktu. Karena bisa jadi, banyaknya kejadian orang-orang yang menunda-nunda shalat disebabkan tiadanya tempat untuk shalat berjamaah. Apalagi di zaman sekarang ini, bangunan-bangunan megah, pusat-pusat perbelanjaan (mall) yang besar, belum memberi jaminan mudahnya akses ke tempat ibadah. Kaum muslimin yang berada disana tidak dipermudah jalannya untuk sampai ke mesjid dan beribadah.

Padahal betapa besarnya pahala yang didapat setiap orang yang melangkahkan kakinya ke mesjid untuk beribadah. Rasulullah SAW. bersabda, "Shalat seseorang (di masjid dengan berjamaah) itu dilebihkan dengan 25 derajat dari shalat yang dikerjakan di rumah dan di pasar. Sesungguhnya jika salah seorang di antara kalian berwudhu kemudian menyempurnakan wudunya lalu mendatangi masjid, tak ada keinginan yang lain kecuali untuk shalat, maka tidaklah ia melangkah dengan satu langkah pun kecuali Allah mengangkatnya satu derajat, dan terhapus darinya satu kesalahan..." (Muttafaqun 'alaih)

Jika demikian, betapa lebih besar lagi ganjaran kebaikan yang akan didapatkan orang yang berwakaf untuk masjid. Karena dia telah membuka dan memudahkan jalan kebaikan bagi sekian banyak orang lain. Silih berganti setiap waktu salat, setiap hari, terus-menerus bahkan hingga ia telah meninggal dunia sekalipun.Belum lagi jika masjid tersebut digunakan juga untuk kegiatan-kegiatan majlis ilmu, pengajian dan kegiatan ibadah lainnya selain dari shalat lima waktu.

Berwakaf untuk memakmurkan masjid, bisa dengan tanah, bisa dengan bahan bangunan, perlengkapannya, karpetnya, Al Qurannya, buku-buku, soundsystem, dan lain sebagainya. Kemudian, dikelola dengan semaksimal mungkin bisa memberikan kenyamanan bagi orang-orang yang berkunjung ke masjid, menambah kekhusyuan ibadah dan membuat orang-orang tertarik untuk datang ke mesjid dan menghidupkannya.

Pemberdayaan suatu masjid dengan banyak dilaksanakannya aktivitas keagamaan, seperti pengajian, majlis ilmu, dan lain-lain, akan menambah ramainya suatu masjid karena banyaknya orang-orang yang mengikuti aktivitas-aktivitas keagamaan tersebut.

b. Pembangunan Sarana Pendidikan

Pemberdayaan dana wakaf untuk pembangunan sarana pendidikan bertujuan, diantaranya:

1) Memfasilitasi kegiatan-kegiatan pendidikan yang dilaksanakan di Yayasan Daarut Tauhid.

2) Menampung lebih banyak siswa/siswi yang bersekolah di Yayasan Daarut Tauhid, terutama siswa/siswi yang dari daerah yang jauh yang 
ingin bersekolah di Daarut Tauhid juga santri-santri yang ada di Yayasan Daarut Tauhid.

3) Memfasilitasi kegiatan pendidikan dengan didukung sarana penunjang lainnya yang membantu kelancaran kegiatan pendidikan sehingga menciptakan kegiatan pendidikan yang lebih kondusif, sehingga menghasilkan siswa/siswi dan santri yang berkualitas.

Sekolah atau madrasah adalah tempat dimana calon-calon ulama, pemimpin, pengusaha, tentara, dokter, arsitek, polisi, olahragawan dan para profesional akan lahir. Sekolah adalah tempat di mana kita mempersiapkan masa depan bangsa dan umat ini dengan generasi penerus terbaik.

Pembangunan sarana pendidikan yang berasal dari dana wakaf dengan dibangunnya sekolah-sekolah, asrama-asrama dan penunjang sarana pendidikan lainnya yang membuat kegiatan pendidikannya lebih kondusif dan nyaman akan melahirkan lebih banyak generasi penerus terbaik yang berakhlak mulia, berbudi pekerti baik dan memiliki ilmu pengetahuan mumpuni. Manusia-manusia yang tauhidnya bersih, akhlaknya mulia dan prestasi gemilang sehingga kelak menjadi manusia yang menebar manfaat bagi dirinya sendiri dan lingkungannya. Manusia yang hatinya senantiasa terikat kepada Allah, dan raganya produktif mengelola dan membangun alam ini sebagai titipan Allah SW'T.

\section{c. Wakaf Produktif}

Wakaf yang telah terhimpun dari muwakif sudah semestinya diberdayakan secara produktif sehingga dapat memberikan kontribusi dalam meningkatkan kesejahteraan masyarakat dan membantu pemerintah dalam meningkatkan kesejahteraan dan taraf hidup masyarakat, baik itu dengan dibangunnya kios-kios usaha, gedung-gedung untuk menyelenggarakan event-event, usaha property atau perumahan, dan lain sebagainya.

Apabila upaya ini dilakukan dengan semaksimal mungkin dengan kerja sama yang baik dengan semua pihak baik itu pemerintah, orang-perorangan atau lembaga-lembaga yang mengelola, memberdayakan dan mengembangkan dana wakaf dalam hal ini nazhir, maka tujuan-tujuan yang ingin dicapai dari adanya pemberdayaan wakaf secara produktif akan tercapai.

Hasil yang Diperoleh melalui Strategi Pemberdayaan Wakaf secara Produktif di Wakaf Daarut Tauhid dalam Upaya Memakmurkan Umat

Konsep Wakaf merupakan alternatif, bagi kehidupan berbangsa Indonesia saat ini yang mengalami keterpurukan ekonomi sehingga berdampak kepada ketidakmakmuran umat. Kesenjangan sosial akan semakin jauh jika praktek pengelolaan dan pemberdayaan wakaf tidak terlaksana dengan baik di masyarakat. Kemiskinan dan kesenjangan sosial ekonomi di sebuah Negara yang kaya dengan 
sumber daya alam dan mayoritas penduduknya beragama islam, seperti Indonesia, merupakan suatu keprihatinan. Jumlah penduduk miskin terus menanjak sejak krisis ekonomi pada 1997 hingga sekarang. Ketidakseriusan penanganan terhadap nasib dan masa depan puluhan juta kaum Mustadb'afin (yang berada di bawah garis kemiskinan) yang tersebar di seluruh tanah air merupakan sikap yang berlawanan dengan semangat dan komitmen Islam terhadap persaudaraan dan keadilan sosial.

Bila ditelaah secara mendalam, ditemukan bukti-bukti empiris bahwa pertambahan jumlah penduduk yang hidup di bawah garis kemiskinan bukanlah karena persoalan kekayaan alam yang tidak sebanding dengan jumlah penduduk (over population), akan tetapi karena persoalan distribusi pendapatan dan akses ekonomi yang tidak adil diakibatkan tatanan sosial yang buruk serta rendahnya rasa kesetiakawanan diantara sesama anggota masyarakat ataupun sebuah sistem pengelolaan dan pemberdayaan harta umat islam yang tidak transparan, akuntable dan tepat sasaran sehingga menyebabkan ketimpangan sosial yang paten diantara bangsa dan umat islam sendiri. Lingkaran kemiskinan yang terbentuk dalam masyarakat kita lebih banyak kemiskinan struktural, sehingga upaya mengatasinya harus dilakukan melalui upaya yang bersifat prinsipil, sistematis, dan komprehensif, bukan hanya bersifat parsial dan sporadis.

Wakaf merupakan pranata keagamaan yang memiliki kaitan secara fungsional dengan upaya pemecahan masalah-masalah kemanusiaan, seperti pengentasan kemiskinan dan kesenjangan sosial yang menyebabkan ketidakmakmuran pada suatu masyarakat akibat perbedaan dalam kepemilikan kekayaan. Wakaf menghapus sumber-sumber kemiskinan meratakan kekayaan dalam arti standar hidup setiap individu lebih terjamin, sehingga mestinya tidak ada orang atau kelompok masyarakat yang menderita, sementara sebagian orang yang lain hidup berlimpah kemakmuran dan kemewahan. Salah satu tujuan wakaf adalah mempersempit perbedaan ekonomi dalam masyarakat hingga batas seminimal mungkin. Wakaf menduduki pada peran pemberdayaan ekonomi masyarakat secara lebih luas untuk meningkatkan taraf hidup dari sekedar mencukupi sehari-hari.

Islam mengenal lembaga wakaf yang merupakan sumber asset yang memberi kemanfaatan sepanjang masa. Namun, pengumpulan, pengelolaan, dan pendayagunaan harta wakaf produktif di tanah air masih sedikit dan ketinggalan dibanding negara lain. Begitupun studi perwakafan di tanah air kita masih terfokus kepada segi hukum fiqih, dan belum menyentuh manajemen perwakafan. Padahal semestinya, wakaf dapat dijadikan sebagai sumber dana dan asset ekonomi yang senantiasa produktif dan memberi hasil kepada masyarakat, sehingga dengan demikian harta wakaf benar-benar menjadi sumber dana dari masyarakat untuk masyarakat dan di masa depan akan dapat memakmurkan umat.

Salah satu lembaga ekonomi islam yang sangat berperan dalam 
pemberdayaan ekonomi umat adalah wakaf. Dalam sejarah, wakaf telah memerankan peran penting dalam pengembangan sosial, ekonomi, dan budaya masyarakat. Hal-hal yang paling menonjol dari lembaga wakaf adalah peranannya dalam membiayai berbagai pendidikan Islam dan kesehatan. Sebagai contoh misalnya di Mesir, Saudi Arabia, Turki dan beberapa Negara lainnya pembangunan dan berbagai sarana dan prasarana pendidikan dan kesehatan dibiayai dari hasil pengembangan wakaf. Kesinambungan manfaat hasil wakaf dimungkinkan oleh berlakunya wakaf produktif yang didirikan untuk menopang berbagai kegiatan sosial dan keagamaan. Wakaf Produktif pada umumnya berupa tanah-tanah pertanian atau perkebunan, gedung-gedung komersial, dikelola sedemikian rupa sehingga mendatangkan keuntungan yang sebagian hasilnya dipergunakan untuk membiayai berbagai kegiatan tersebut. Bahkan dalam sejarah, wakaf sudah dikembangkan dalam bentuk apartemen, ruko dan lain-lain. Disamping apartemen dan ruko, terdapat wakaf toko makanan, pabrik-pabrik, dapur umum, mesin-mesin pabrik, alat-alat pembakar roti pemeras minyak, tempat pemandian, dan lain-lain. Wakaf Produktif ini kemudian dipraktekkan di berbagai Negara sampai sekarang. Hasil dari pengelolaan wakaf tersebut dimanfaatkan untuk menyelesaikan berbagai masalah sosial ekonomi umat.

Salah satu bentuk wakaf produktif dalam ijtihad ulama masa kini adalah bentuk Wakaf Uang yang memang belum lama ini dikenal di Indonesia. Padahal Wakaf Uang (Wakaf Tunai) tersebut sebenarnya sudah cukup lama dikenal di dunia Islam, yakni sejak zaman kemenangan dinasti mamluk, para ahli fikih memperdebatkan boleh atau tidaknya uang, diwakafkan. Ada sebagian ulama yang membolehkan wakaf uang, dan sebagian ulama melarangnya, dan masing-masing mempunyai alasan yang memadai. Meskipun wakaf uang sudah dikenal pada masa Imam Mazhab, namun wakaf uang baru akhir-akhir ini mendapat perhatian para ilmuan dan menjadi bahan kajian intensif. Di berbagai Negara Wakaf Uang sudah lama menjadi kajian, dan bahkan sudah dipraktekkan serta diatur dalam peraturan perundang-undangan. Yang menjadi masalah di berbagai tempat baik di Indonesia maupun di Negara lain adalah pengelolaannya. Tidak jarang Wakaf dikelola dengan manajemen yang kurang bagus sehingga dapat mengakibatkan Wakaf tersebut berkurang atau hilang. Padahal Wakaf sebagai harta Allah tidak boleh berkurang sedikitpun. Agar Wakaf dapat dikelola oleh Nąhir yang profesional dan harta wakafnya dapat berkembang dengan baik, maka wakaf harus dikelola secara transparan dan akuntabilitas.

Salah satu contoh wakaf produktif yaitu dalam bentuk wakaf uang yang diberdayakan dengan dibangunnya sarana-sarana ibadah, pendidikan, dan sarana ekonomi umat yang nantinya bisa diambil manfaatnya oleh umat.

Di Indonesia Gerakan Wakaf Uang ini sudah dijalankan oleh salah satu lembaga di bawah Yayasan Daarut Tauhid yaitu Wakaf Daarut Tauhid. Lembaga ini mempunyai tujuan dalam pemberdayaan dana wakafnya yaitu untuk 
memakmurkan umat dan dilakukan secara produktif.

Upaya-upaya yang dilakukan dalam pemberdaayan dana wakaf secara produktif ini dengan dibangunnya sarana ibadah, sarana pendidikan dan sarana ekonomi umat, diantaranya penyediaan kios-kios yang disewakan kepada orang ingin berdagang, membangun gedung-gedung untuk event-event kemudian disewakan, usaha property atau perumahan, dan lain sebagainya.

Oleh karena itu, dengan strategi pemberdayaan wakaf produktif dengan banyak dibangunnya sarana ibadah yang lebih luas dan dilengkapi dengan sarana penunjang yang membuat nyaman orang yang berkunjung ke mesjid, kemudian dibangunnya sarana pendidikan yang lebih banyak, luas dan membuat suasana kegiatan belajar-mengajar lebih kondusif, serta disediakan sarana-sarana ekonomi umat yang banyak dan beragam.

Dengan demikian, kemakmurkan umat akan tercapai dengan dilihat dari beberapa hal berikut ini :

a. Semakin banyaknya orang untuk datang ke mesjid karena luas dan merasa nyaman bila berada di masjid dan menghidupkannya dengan kegiatankegiatan keagamaan.

b. Adanya pembangunan sarana pendidikan yang nyaman dan lebih luas maka suasana kegiatan pendidikan yang dilakukan akan kondusif.

c. Disediakannya sarana ekonomi umat dari dana wakaf, maka orang yang mempunyai modal yang tidak terlalu besar untuk usaha bisa membuka usaha dengan menyewa kios-kios yang sudah dibangun dari dana wakaf.

Oleh karena itu, apabila dana wakaf yang telah terhimpun dari para wakif dikelola dengan manajemen yang profesional dan diberdayakan secara produktif maka kemakmuran umat akan tercapai, meskipun belum tercapai secara keseluruhan dan belum mencakup ke masyarakat yang lebih luas, hanya masyarakat yang tinggal di sekitar Yayasan Daarut Tauhid.

\section{PENUTUP}

Berdasarkan hasil penelitian yang telah dilakukan dengan judul skripsi mengenai "Strategi Pemberdayaan Wakaf Produktif dalam Upaya Memakmurkan Umat" maka dapat diambil beberapa kesimpulan, diantaranya: a) Sasaran pemberdayaan wakaf dan wakaf produktif di lembaga Wakaf Daarut yaitu diperuntukkan dalam pembangunan dan penyediaan berbagai sarana, baik itu sarana ibadah, sarana pendidikan dan sarana-sarana ekonomi umat. b). Pembangunan Sarana Ibadah. Dana wakaf yang telah terhimpun untuk penyediaan sarana ibadah di Wakaf Daarut Tauhid didonasikan dalam pembangunan dan perluasan masjid Daarut Tauhid dan menyediakan untuk 
A.Nurbayani

masjid sarana penunjang lainnya. c).Pembangunan Sarana Pendidikan. Donasi wakaf di Wakaf Daarut Tauhid diperuntukkan untuk pembangunan asramaasrama dan ruang kelas untuk belajar yang lebih banyak dan nyaman karena siswa/siswa dan santri Daarut Tauhid semakin banyak dan belum tersedia nya asrama dan ruang kelas yang memadai. d)Pembangunan Sarana Ekonomi Umat. Wakaf Daarut Tauhid menyediakan sarana ekonomi umat, diantaranya menyediakan kios-kios usaha yang disewakan termasuk area foodcourt, membangun gedung-gedung serba guna yang disewakan untuk event-event, pameran, pernikahan dan lain sebagainya, kemudian didonasikan pada usaha property atau perumahan.

Tujuan dari adanya berbagai strategi dalam pemberdayaan dana wakaf produktif yaitu untuk menyediakan berbagai sarana-sarana baik itu sarana ibadah dan sarana pendidikan yang dapat digunakan untuk beribadah dan digunakan untuk kegiatan pendidikan. Sedangkan dengan adanya sarana ekonomi umat dari dana wakaf yang dapat diambil manfaatnya oleh umat.

Hasil yang diperoleh dari pemberdayaan wakaf produktif selain untuk memakmurkan umat karena tersedianya berbagai sarana ibadah yang aman dan nyaman juga untuk memberdayakan ekonomi umat untuk lebih maju dan berkembang dengan diberdayakannya dana wakaf secara produktif sehingga taraf ekonomi umat lebih meningkat.

Berikut beberapa saran dan rekomendasipada lembaga wakaf yaitu Wakaf Daarut Tauhid, berdasarkan penelitian yang telah saya lakukan, diantaranya: Dana wakaf yang terhimpun agar diberdayakan semaksimal mungkin sesuai syariah Islam dan diperuntukkan kepada usaha-usaha produktif yang lebih banyak dan lebih luas sampai ke daerah-daerah yang membutuhkan. . Meningkatkan upaya penyampaian informasi mengenai wakaf kepada umat agar jumlah muwakif (orang yang berwakaf) meningkat dan yang telah menjadi muwakif diajak terus untuk berwakaf, agar dana wakaf yang terhimpun semakin meningkat.. Menambah jumlah karyawan (nazhir), dengan kualifikasi nazhir yang profesional dan yang mengetahui tentang wakaf secara mendalam, agar dalam pemberdayaan dana wakaf berjalan dengan lancar. Melakukan pembinaan dan pelatihan secara terus menerus kepada karyawan/nazhir yang sudah ada, agar terbentuknya nazhir (pengelola wakaf) yang lebih profesional. Koordinasi antara semua karyawan/santri karya untuk lebih diintensifkan, sehingga terciptanya rasa kekeluargaan yang erat serta upaya-upaya yang dilakukan dalam penghimpunan, pengelolaan, pengembangan dan pemberdayaan dana wakaf lebih maksimal.

\section{DAFTAR PUSTAKA}

Anggota IKAPI. (2012). Kompilasi Hukum Islam. Bandung: Fokus Media. Departemen Agama RI. (1986). Ilmu Fiqh. Jakarta. 
Departemen Agama RI. (2000). Al'aliyy Al Quran dan Terjemah. Bandung: CV Diponogoro.

Departemen Agama RI. (2007). Undang-Undang Nomor 41 Tabun 2004 Tentang Wakaf. Jakarta.

Direktorat Pemberdayaan Wakaf, Depag RI. Y. Jakarta : Fiqib Wakaf. Jakarta.

Djunaidi, A \& Al-Asyhar,H. (2007). Menuju Era Wakaf Produktif. Depok: Mumtaz Publishing.

Edward Russell-Walling. (2008). 50 Terobosan Manajemen yang Perlu Anda Ketabui. Jakarta: Erlangga.

Erni \& Kurniawan. (2010). Pengantar Manajemen. Jakarta: Kencana.

Hariwijaya. (2010). Strategi Lobi dan Negosiasi. Jakarta: PT. Suka Buku.

Hasibuan.M.S.P. (2001). Manajemen, Dasar, Pengertian, dan Masalah. Jakarta: PT Bumi Aksara.

John M. Ivancevich, Robert Konopaske \& Michael T. Matteson. (2005). Perilaku dan Manajemen Organisasi Jilid 1 dan 2. Jakarta: Erlangga.

Kementrian Agama RI. (2013). Pemberdayaan Tanah Wakaf Produktif Strategis. Jakarta.

Komara. (2005). Peranan DMI JABAR dalam Mengoptimalkan Fungsi Masjid bagi Pemberdayaan Ekonomi Ummat.

Manchendrawaty. N \& Safei,A.A. (2001). Pengembangan Masyarakat Islam. Bandung : PT Remaja Rosdakarya.

Mardani. (2012). Fiqh Ekonomi Syariah. Jakarta: Kencana.

Muherdi. (2006). Strategi Pengurus BAZIS dalam Meningkatkan Pengelolaan Zakat, Infak dan Shadaqah.

Nazir, M. (2014). Metode Penelitian. Bogor: Ghalia Indonesia.

Nurul Huda \& Mohamad Heykal. (2010). Lembaga Keuangan Islam, Tinjauan Teoretis dan Praktis. Jakarta: Kencana.

Purnomo,S.H.\& Zulkieflimansyah. (2007). Manajemen Strategi. Jakarta: Lembaga Penerbit Fakultas Ekonomi Universitas Indonesia.

Sadiah, Dewi. (2014). Metode Penelitian Dakwah, Pendekatan Kualitatif dan Kuantitatif. Bandung: CV. Mimbar Pustaka.

Saebani,B.A. (2008). Metode Penelitian. Bandung: Pustaka Setia.

Saladin. D. (1999). Manajemen Strategi dan Kebijakan Perusahaan. Bandung: Linda karya.

Salusu, J. (1996). Pengambilan Keputusan Stratejik untuk Organisasi Public dan Organisasi Nonprofit. Jakarta: PT. Gramedia

Shomad. A. (2010). Hukum Islam, Penormaan Prinsip Syariah dalam Hukum Indonesia. Jakarta: Kencana.

Solihin.I. (2010). Pengantar Manajemen. Jakarta: Erlangga.

Suhendi. H. (2011). Fiqh Muamalah. Jakarta: PT RajaGrafindo Persada. 
A.Nurbayani

Syukir.A.(1983). Dasar-dasar Strategi Dakwah. Surabaya: Al-Ikhlas.

T. Jacob (ed.). (2000). Membongkar Masyarakat Madani. Yogyakarta: Pustaka Pelajar.

Udaya, J. Lic., Ec. (1994). Teori Organisasi (Struktur, Desain dan Aplikasi). Jakarta: Arcan. 